\title{
MOBLOG SEBAGAI KONVERGENSI NEW MEDIA
}

\author{
Lady Joanne Tjahyana \\ Jurusan Ilmu Komunikasi, Fakultas Ilmu Komunikasi, \\ Universitas Kristen Petra \\ Jalan Siwalankerto 121-131 Surabaya 60236 \\ email:joanne@peter.petra.ac.id
}

\begin{abstract}
Moblog refers to blogging activities through mobile devices such as PDA and cell phone. Moblog is developed from previous well known computer used media application called blog. With the improvement of communication technology development, mobile blog activity can be done through cellular phone. Moblog is a form of new media convergence, instead of old media convergence. This can be seen from new media's characteristics in moblogging that are Digitality, Interactivity, Dispersality, and Virtuality. Moblog is also combined from several new media applications and devices that are blog, cell phone, digital camera, internet, and several computer functions. There are several convergencies implications because of moblog that are media consumer behaviour, prosumer techonology production, and media ownership concentration. In conclusion, moblog is considered as a new media convergencies form that has some new media characters and gives some convergencies impact.
\end{abstract}

Keywords: Moblog, Media Convergention, New Media

\section{PENDAHULUAN}

Moblog adalah singkatan dari Mobile Blog, yaitu aktivitas blogging yang dilakukan melalui PDA, HP dan perangkat mobile lainnya. (Onggo, 2006). Aktifitas blog itu sendiri sudah sangat populer berkat penyedia layanan blog pertama, bloger.com. Seiring semakin berkembangnya teknologi telepon selular dengan terbenamnya kamera digital dan jaringan GPRS, maka dimungkinkan adanya aktifitas mobile blogging tersebut. Maka pada tahun 1995, aktivitas posting moblog pertama dilakukan oleh seseorang bernama Steve Mann, hingga sekarang telah banyak sekali bermunculan penyedia layanan moblog terkemuka, seperti moblog.co.uk, m.flickr.com, vox.com, moblog.com.sg, mobylog.com, typepad.com, m.youtube.com, twango.com dan masih banyak lagi. Di era new media ini, banyak sekali bentuk-bentuk media baru yang lahir karena adanya konvergensi dari dua atau lebih media-media pendahulunya. Tak dapat dipungkiri, moblog merupakan salah satu bentuk konvergensi new media.

Secara khusus artikel ini akan membahas Moblog sebagai salah satu bentuk Konvergensi New Media, dilihat dari faktor dan dampak konvergensi media, beserta karakteristik New Media itu sendiri.

Faktor-faktor konvergensi media berdasarkan definisi konvergensi media yaitu adanya penggabungan proses-proses komputer, telekomunikasi, dan media dalam lingkungan digital. (Pavlik, 2004) 


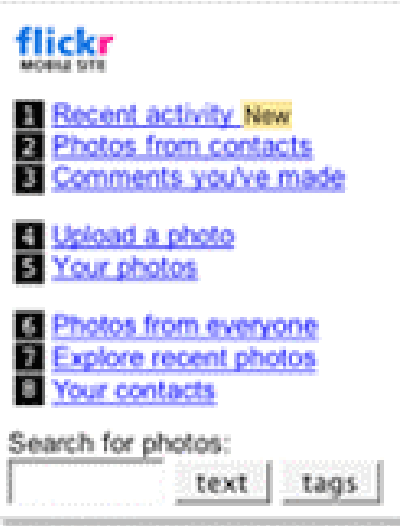

Sumber: http://www.flickr.com/tools/mobile

\section{Gambar 1. Screenshot Situs Moblog m.flickr.com}

Dampak adanya konvergensi media terhadap konsumen dalam menggunakan media, beserta kepemilikan media adalah:

1. Peningkatatan konsumsi media

2. Teknologi Prosumer dalam media

3. Konsentrasi kepemilikan media

(Pavlik, 2004)

Karakterisitik New Media tersebut antara lain:

1. Digitality

2. Interactivity

3. Dispersality

4. Virtuality

(Lister, 2003)

\section{PEMBAHASAN}

\section{Moblog Sebagai Bentuk Konvergensi Media}

Dilihat dari pengertian konvergensi media, maka konvergensi media memiliki beberapa faktor, yaitu proses-proses komputer, telekomunikasi, media, dan lingkungan digital. Penjelasan atas beberapa faktor tersebut mencakup :

\section{Proses-proses komputer}

Jika dilihat dari langkah-langkah melakukan moblogging, maka akan didapatkan proses-proses komputer antara lain:

\section{Posting melalui Email}

Yang paling nampak adalah proses posting yang dilakukan dengan cara email. Bahkan konten multimedia berupa foto dan video dapat di-posting sebagai sebuah attachment pada email tersebut. Memang tidak semua telepon selular memiliki fasilitas email, namun fungsi email ini bisa digantikan dengan melakukan MMS. Karena dengan MMS, seorang blogger juga dapat mengirimkan pesan multimedia ke sebuah alamat email tertentu yang telah disediakan oleh penyedia layanan moblog khusus untuk account pribadi seorang moblogger, sebagai sebuah posting pada blog. 


\section{Moblogwalking}

Proses komputer lain yang ada pada moblogging adalah pada saat kita melakukan browsing pada sebuah situs moblog ataupun pada situs blog pada telepon selular melalui perangkat lunak berupa XHTML browser yang sudah di-install pada telepon selular tersebut. Saat ini semua produsen telepon selular telah menanamkan XHTML browser pada produk - produk telepon selular terkini, sehingga pengguna dapat browsing internet pada telepon selular. Jika pada komputer kita dapat melakukan blogwalking, maka pada telepon selular kita juga dapat melakukan moblogwalking. Teknologi XHTML browser yang terbenam pada produk telepon selular terkini, bahkan memungkinkan pengguna yang adalah moblogger untuk memberi comment ataupun me-reply sebuah comment pada situs moblog.

Selain itu seorang moblogger juga dapat melakukan download dan upload gambar dan konten internet lain dari sebuah situs moblog, seperti halnya pada browser komputer. Untuk melakukan posting langsung melalui XHTML browser sampai saat artikel ini ditulis hanya dimungkinkan untuk dilakukan pada browser internet pada perangkat PDA.

\section{Telekomunikasi}

Media utama yang memfasilitasi aktifitas moblogging adalah telepon selular, dan tentu saja telepon selular merupakan sebuah media telekomunikasi. Telepon selular merupakan media telekomunikasi synchronous dimana proses komunikasi dapat dilakukan secara langsung, sedangkan sebagai bentuk media telekomunikasi, moblog merupakan sebuah media telekomunikasi secara asynchronous. Komunikasi yang terjadi pada aktifitas moblogging merupakan proses komunikasi secara tidak langsung, di mana moblogger dapat meninggalkan comment pada posting sebuah blog dan mendapatkan reply atas comment tersebut, namun tentu saja akan terdapat jeda waktu sebelum mendapatkan balasan, menunggu pemilik blog melakukan cek comment pada posting di blognya. Adapun reply dapat dilakukan pada blog penerima comment namun pada blog pemberi comment.

\section{Media}

Moblog itu sendiri sebenarnya adalah sebuah bentuk media baru yang merupakan penggabungan berbagai media. Secara perkembangan teknologi komunikasi dapat dilihat bahwa moblog merupakan penggabungan media komputer, internet, telepon selular dan kamera digital. Media internet meliputi teknologi media berupa blog itu sendiri. Sedangkan secara fungsi, blog itu sendiri sebenarnya merupakan penggabungan sebuah media jurnalisme dengan sebuah media personal website. Untuk lebih jelasnya, dapat dilihat pada Gambar 1 berikut ini.

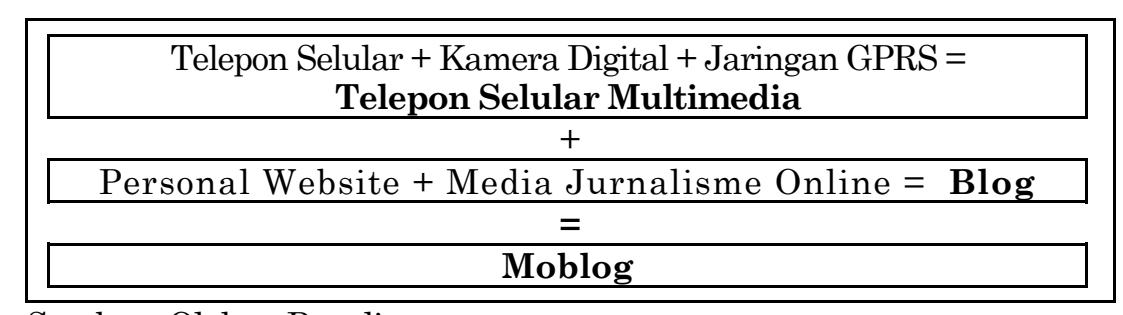

Sumber : Olahan Penulis 


\section{Gambar 2. Bagan Konvergensi Media Moblog}

\section{Lingkungan Digital}

Media-media yang terkonvergensi dalam moblog adalah bentuk-bentuk media digital. Telepon selular adalah bentuk digital dari sebuah telepon analog. Kamera digital juga merupakan bentuk digital dari sebuah kamera analog. Proses-proses komputer yang ada pada aktifitas moblogging juga tidak lain adalah proses-proses digital. Lingkungan digital tersebut akan memungkinkan semakin berkembang dengan munculnya teknologi yang lebih inovatif sehingga bukannya tidak mungkin moblog dikemudian hari akan memiliki fasilitas yang lebih canggih.

\section{Moblog Ditinjau dari Implikasi Konvergensi Media}

Konvergensi media telah membawa dampak yang cukup signifikan dalam berbagai aspek kehidupan, terutama dalam perilaku konsumen dalam menggunakan sebuah media untuk berkomunikasi, serta membawa dampak pada konsentrasi kepemilikan media saat ini.

\section{Peningkatan Konsumsi Media}

Tidak dapat dipungkiri bahwa sejak munculnya internet, maka komunikasi antar umat manusia menjadi tanpa batasan waktu dan tempat. Dengan semakin berkembangnya perangkat mobile berupa telepon selular yang sudah dilengkapi dengan teknologi GPRS untuk melakukan akses internet, tentu saja akan semakin membuat proses komunikasi dan aliran informasi menjadi real time.

Jika seorang blogger yang ingin posting sebuah foto, maka yang harus dilakukan adalah memindahkan file foto digital tersebut dari perangkat foto digital ataupun telepon selularnya untuk terlebih dahulu di simpan dalam hardisk komputer. Setelah itu dibutuhkan koneksi internet untuk kemudian posting baru bisa dilakukan melalui account situs blog-nya. Maka sebuah momen penting yang ingin segera dipublikasikan masih harus menunggu proses-proses tersebut. Dengan Moblog maka semua bisa terjadi secara real time. Begitu momen diabadikan melalui foto digital yang terbenam dalam telepon selular, maka saat itu juga moblogger dapat langsung posting ke situs blognya melalui akses GPRS dari telepon selularnya.

Sebaliknya jika ingin melihat posting terbaru pada sebuah moblog, juga dapat langsung dilakukan secara real time dari telepon selular, tanpa harus menunggu tersedianya komputer.

\section{Teknologi Prosumer dalam media}

Teknologi Prosumer menurut Martin Lister adalah teknologi yang memungkinkan pengguna untuk menjadi seorang produsen maupun konsumen sekaligus dalam pemanfaatan sebuah media. (Lister, 2003)

Dalam moblogging, sebagai seorang konsumen, moblogger dapat melakukan aktifitas moblogwalking untuk sekedar berjalan-jalan dari satu situs moblog ke situs moblog lainnya untuk kemudian meninggalkan pesan bagi pemilik situs moblog tersebut. Moblogger juga berperan sebagai seorang konsumen ketika membaca sebuah posting yang ada pada situs moblog. Jika tertarik pada isi posting sebuah moblog, maka dengan mudahnya isi posting tersebut baik berupa teks maupun image, dapat di download dengan mudah dan disimpan dalam memori telepon selular. 
Sebagai seorang produsen, seorang moblogger dapat melakukan posting pada moblog miliknya, baik berupa tulisan beserta image. Bahkan saat ini telah muncul istilah citizen journalism, karena setiap warga dapat menjadi seorang jurnalis. Hal ini dimungkinkan dengan adanya teknologi prosumer dalam media blog, yang memungkinkan setiap orang untuk melaporkan kejadian apapun itu, tanpa proses editing yang berbelit-belit, dalam situs blognya. Tentu saja dengan moblog proses jurnalisme warga mulai dari pengambilan gambar melalui kamera, proses penulisan artikel, dan posting tersebut dapat menjadi real time melalui telepon selular.

\section{Konsentrasi Kepemilikan Media}

Konvergensi media merupakan penggabungan berbagai bentuk media, menjadi sebuah bentuk media baru. Hal ini tentu saja berpengaruh pada kepemilikan sebuah media. Sejak dimungkinkanya melakukan moblogging pada telepon selular, beberapa vendor telepon selular terkemuka mulai menggandeng vendor situs moblog untuk bekerja sama dalam rangka memudahkan penguna untuk melakukan moblogging lewat perangkat telepon selularnya.

Nokia menggandeng flickr.com dan vox.com, yaitu para penyedia layanan moblog terkemuka, untuk menyediakan fitur Nokia LifeBlog, yang memungkinkan moblogger untuk langsung mengirim sebuah image sebagai posting moblog. Tentu saja tidak perlu melalui proses email atau MMS atau membuka situs moblog terlebih dahulu. Cukup dengan memilih menu "send" dengan modus "web upload", maka otomatis image tersebut menjadi sebuah posting pada situs blog kita. Tetapi proses ini juga tidak terlepas dari langkah-langkah setting terlebih dahulu pada perangkat telepon selular Nokia tersebut dan melakukan sign up account pada situs moblog.

Saingan terdekat Nokia, Sony Ericsson juga telah bekerjasama membenamkan fitur moblog BlogThis! pada perangkat telepon selularnya, dengan vendor blog pertama di dunia yaitu blogger.com. Bagi pemilik telepon selular Sony Ericsson yang telah memiliki account di blogger, cukup dengan memilih menu "send to blog" maka secara otomatis hanya dengan melakukan konfirmasi melalui proses claim token, image tersebut akan menjadi sebuah posting pada situs moblog pribadi. Bahkan setiap perangkat telepon selular Sony Ericsson telah memiliki ID tersendiri yang terkoneksi dengan moblog pribadi pemilik telepon selular tersebut.

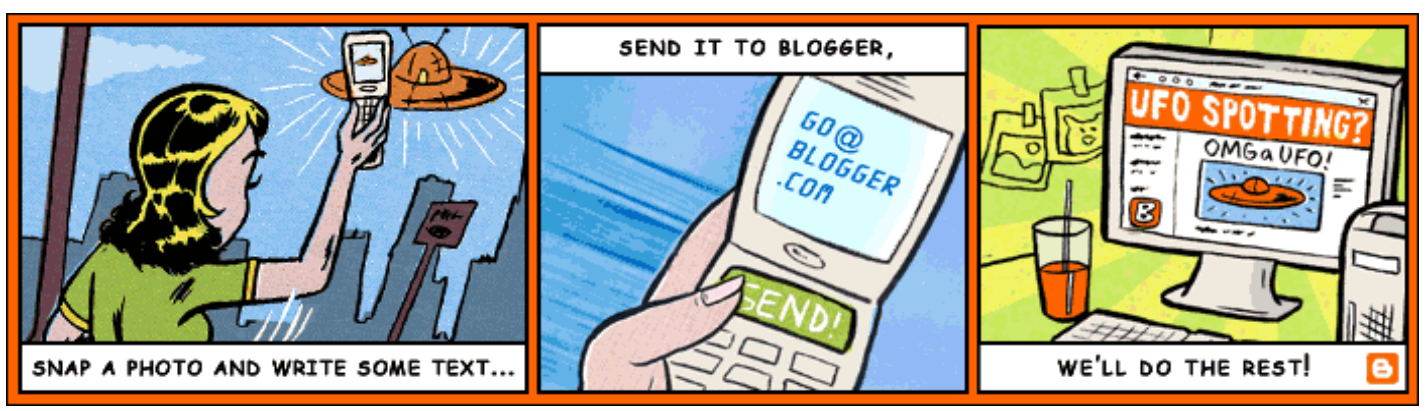

Sumber: http://www.blogger.com/mobile-start.g

\section{Gambar 3. Blogger Mobile}

Saat ini banyak sekali vendor-vendor telepon selular yang berlomba-lomba untuk menyediakan fasilitas kemudahan bagi moblogger untuk melakukan aktifitas moblogging. Seperti iPhone yang telah menggandeng typepad.com untuk menyediakan layanan moblogging bagi pengguna iPhone. Di kemudian hari, layanan 
moblog akan menjadi suatu fitur wajib yang harus disediakan oleh para vendor telepon selular.

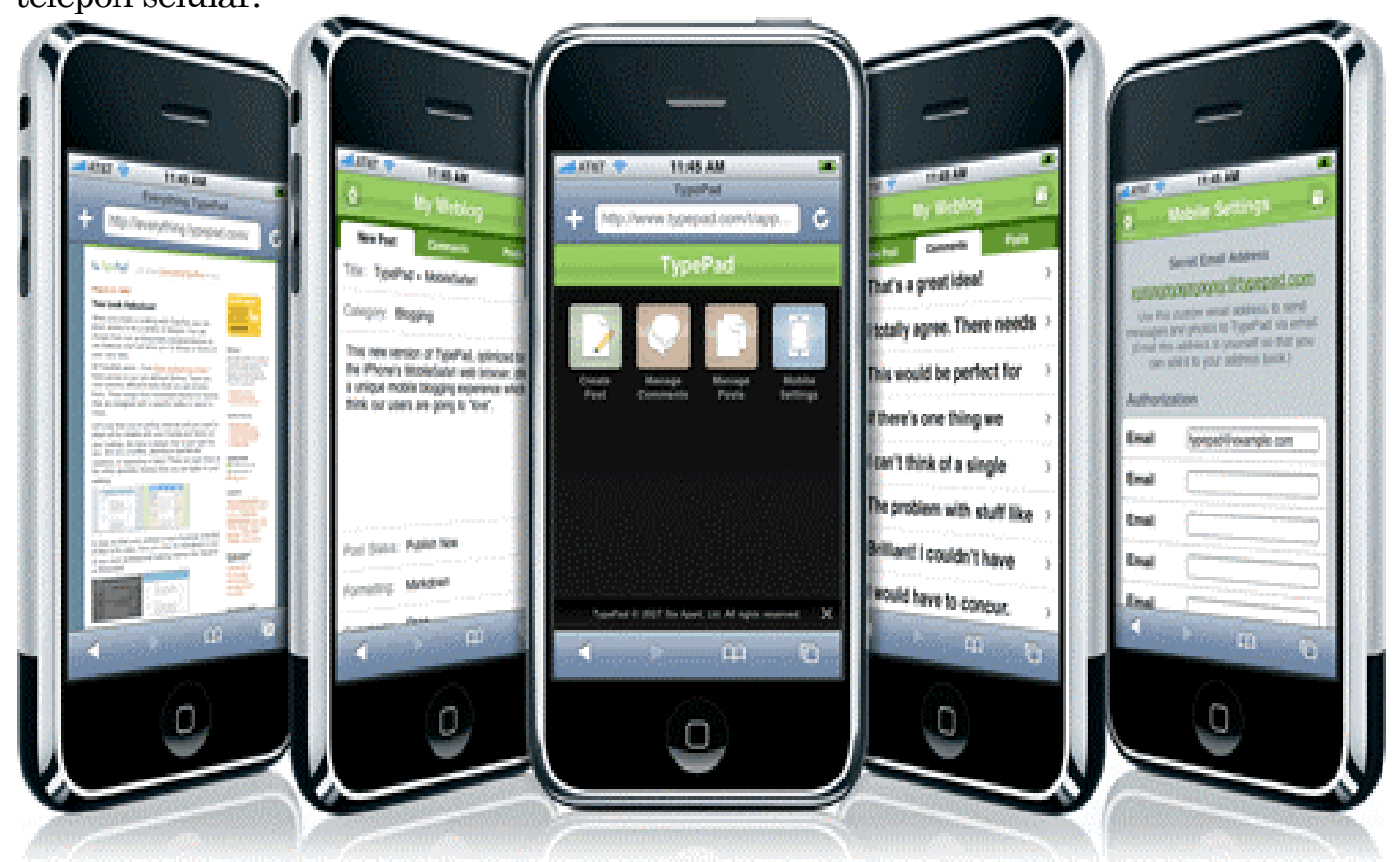

Sumber: http://everything.typepad.com/blog/mobile/index.html

\section{Gambar 4. iPhone dan TypePad}

\section{Moblog Sebagai Bentuk New Media}

Pada media konvensional seperti media cetak, sering terdapat ralat pada terbitan berikutnya mengenai kesalahan editorial pada edisi sebelumnya, karena sudah terlanjur dicetak dan diterbitkan. Hal ini disebabkan karena media tersebut merupakan media analog. Moblog merupakan media digital yang dapat berubah setiap saat, meskipun ada kesalahan pada sebuah posting dan sudah terlanjur di publikasikan, tetap saja di kemudian hari dapat dilakukan perubahan, bahkan dihapus dari moblog kita.

Tidak akan ada yang tahu mengenai perubahan yang telah dilakukan, meskipun demikian tetap saja ada kelemahannya. Karena bersifat dinamis, maka konten dari sebuah media digital termasuk moblog, jika ingin dijadikan sebuah referensi karya ilmiah, harus mencantumkan tanggal pengaksesan situs. Hal ini untuk mencegah terjadinya kerancuan di kemudiah hari karena konten yang sudah berubah ataupun bahkan telah hilang dari dunia maya. Selain itu royalti juga menjadi masalah besar pada moblogsphere. Setiap posting yang ada dapat begitu mudahnya di download dan dipergunakan lagi untuk kepentingan lainnya oleh moblogger lain, tanpa ada tuntutan hukum yang jelas. Seorang moblogger juga tidak dapat begitu saja mengklaim sebuah posting atau elemen lain dalam moblognya adalah hasil ciptaan orisinilnya.

\section{Interactivity}


Dalam aktifitas moblogging, tentu saja interaktifitas adalah hal yang sangat signifikan. Interaktifitas terjadi ketika seorang moblogger memberi comment kepada posting yang ada pada sebuah situs moblog, dan pemilik moblog tersebut akan memberi reply pada comment yang sudah diberikan. Reply tersebut bisa langsung di berikan sebagai sebuah comment pada posting yang sama, ataupun dapat berupa kunjungan balik pada situs moblog pemberi comment dan kemudian memberi comment juga pada posting yang ada di situs moblog tersebut. Banyak pula penyedia layanan moblog yang memberi fasilitas message sehingga para moblogger dapat saling berkirim pesan.

\section{Hypertextuality}

Semua proses moblogging, mulai dari moblogwalking, memberi dan menjawab comment, hingga posting dari sebuah telepon selular, tidak akan mungkin terjadi tanpa adanya teknologi hypertext. Teknologi yang merupakan bahasa pemrograman untuk jaringan internet ini juga berlaku bagi jaringan internet pada aktifitas moblogging. Secara teknis, dengan hypertext, sebuah situs moblog dapat mengirimkan data kepada server moblog, dan sebaliknya hypertext pula yang akan melakukan proses pengambilan data dari server untuk dapat dinikmati pada XHTML browser pada telepon selular seorang moblogger.

\section{Dispersal}

Terkait dengan adanya teknologi prosumer, maka terjadi perbedaan mencolok antar centralised media dan dispersed media. Centralised media dapat dilihat pada media analog seperti media cetak hingga media broadcasting radio dan televisi. Hal ini disebabkan karena produksi media konvensional tersebut terpusat pada sebuah tempat produksi, baik itu sebuah percetakan maupun stasiun radio dan televisi. Proses produksi juga terpusat dan hanya dapat dilakukan oleh para kru redaksi, melalui proses seleksi lowongan kerja yang ketat.

Moblog, yang merupakan salah satu bentuk dispersed media, lahir dari adanya teknologi prosumer, sehingga menyebabkan proses produksi sebuah posting artikel pada situs moblog dapat dilakukan oleh siapa saja, di mana saja dan kapan saja. Proses produksi sebuah moblog tidak terpusat pada kru tim redaksi saja, karena siapapun dapat menjadi seorang moblogger. Berkat digitalisasi dan jaringan GPRS pada telepon selular, isi dari sebuah moblog juga dapat dinikmati oleh setiap moblogger yang ada di belahan dunia manapun yang memiliki telepon selular, tanpa terbatas dan terpusat oleh area distribusi dan frekuensi yang terbatas pada area tertentu.

\section{Virtuality}

Virtuality yang dimaksud di sini adalah terbentuknya komunitas - komunitas virtual pada dunia maya. Dengan adanya interaktifitas pada aktivitas moblogging maka banyak bermunculan adanya komunitas - komunitas blogger pada blogsphere. Komunitas tersebut terbentuk atas dasar kepentinggan yang sama, baik berupa minat ataupun golongan yang sama diantara para moblogger. Komunitas moblogger dapat menjadi suatu sarana jejaring sosial yang populer, karena dapat dilakukan langsung dari telepon selular tanpa terbatas ruang dan waktu. Justru komunitas 
virtual inilah yang menjadi daya tarik utama dari aktifitas moblogging. Apalagi jika dapat berkomunitas dengan berbagai macam moblogger dari belahan dunia manapun.

\section{KESIMPULAN}

Moblog bukan hanya sebuah konvergensi media namun merupakan bentuk konvergensi New Media. Media-media yang membentuk moblog itu sendiri sebenarnya sudah merupakan sebuah bentuk New Media. Media-media seperti telepon selular, jaringan internet, kamera digital, dan blog itu sendiri memiliki karakteristik new media. Selain itu media-media yang terkonvergensi dalam moblog tersebut juga merupakan konvergensi dari media-media pendahulunya.

Faktor-faktor konvergensi media terlihat jelas moblog yang merupakan konvergensi new media. Selain itu moblog telah membawa dampak konvergensi media yang cukup signifikan terhadap perilaku konsumen media, dan terhadap konsentrasi kepemilikan media. Selanjutnya moblog dapat disebut sebagai bentuk new media karena adanya karakteristik new media, yang terdapat baik dari segi teknologi maupun aktifitas moblogging. Moblog dapat disebut sebagai konvergensi new media karena media-media yang terkonvergensi dalam moblog itu sendiri sudah merupakan bentuk-bentuk new media.

\section{DAFTAR PUSTAKA}

Bob J. Onggo. 2006. CEO Blogging. Yogyakarta: Andi Offset

Blogger: Blogger Mobile. 2008. 11 January

http://www.blogger.com/mobile-start.g

Everything TypePad:Mobile. 2008. 11 January http://everything.typepad.com/blog/mobile/index.html

Flickr: Mobiles Tools. 2008. 11 January http://www.flickr.com/tools/mobile/

Flickr:Help:Flickr and Nokia. 2008. 11 January. http://www.flickr.com/help/nokia/

Lister, Dovey, Giddings, Grant, and Kelly. 2003. New Media: A Critical Introduction. London: Routledge.

Pavlik, McIntosh. 2003. Converging media [-]: an introduction to mass communication. Boston: Pearson Education, 2004.

Using Blogger with Your Sony Ericsson Mobile Device. 11 Januariy 2008. http://help.blogger.com/bin/answer.py?answer=72578\&topic=12462 